\title{
LECTURES ON HOMER AT NON-CATHOLIC UNIVERSITIES IN CENTRAL EUROPE AS ATTESTED IN MATTHAEUS COLLINUS'S SPECIMEN STUDII AC LABORUM (1557) AND JOACHIM CAMERARIUS'S COMMENTARIUS EXPLICATIONIS PRIMI LIBRI ILIADOS (1538)
}

\author{
MARCELA SLAVÍKOVÁ
}

\begin{abstract}
The purpose of this paper is to describe the structure, content, and objectives of lectures on Homer that were given by two prominent intellectuals of the early sixteenth century, namely Matthaeus Collinus (1516-1566) and Joachim Camerarius the Elder (1500-1574). The paper comprises a detailed analysis of Collinus's Specimen studii ac laborum (1557), whose main points are then compared with those included in Commentarius explicationis primi libri Iliados (1538) by Camerarius. Conclusions are drawn as to whether there is a direct relation between the two volumes.
\end{abstract}

Keywords: lectures on Homer in the early sixteenth century - Didactics of Humanist Greek - Matthaeus Collinus - Joachim Camerarius the Elder - Greek Classes at the University of Prague - Specimen studii ac laborum by Matthaeus Collinus - Commentarius explicationis primi libri Iliados by Joachim Camerarius

DOI: $10.14712 / 23365730.2020 .28$

When, in 1541, Matthaeus Collinus, ${ }^{1}$ who had learned Greek in Wittenberg, was appointed to be the first professor of Greek at the University of Prague, he approached the task with meticulous care, as can be inferred from his Specimen studii ac laborum. The volume, which is a manuscript collection of lectures Collinus gave on Homer's Iliad and Vergil's

1 Matthaeus Collinus (1516-1566) first studied at the University of Prague, but soon he proceeded to Wittenberg University, where he attended Philipp Melanchthon's lectures and learned Greek from Veit Winsheim. After his graduation from Wittenberg, Collinus returned to Prague, and in 1541 he was appointed professor at the department of Greek studies, which had only been established four years earlier. Apart from lectures on Homer's Iliad, he read major Latin authors and also gave Greek grammar classes, as is apparent from his Specimen studii ac laborum. It seems that he was also preparing a Greek grammar, following Melanchthon's example. For further information on Collinus and his prominent position in the so-called Hodějovský circle see Lucie Storchová (ed.), Bohemian School Humanism and its Editorial Practices (ca. 1550-1610), Turhout 2014, pp. 73-76; Antonín TruHLÁr̆ - Karel HrdinA - Josef HeJNIC - Jan MarTínEK, Rukovět' humanistického básnictvi $v$ Čechách a na Moravě od konce 15. do začátku 17. století [A Handbook of Humanist Poetry in Bohemia and Moravia from the End of the 15th Century until the Beginning of the 17th Century], Praha 1966, pp. 415-451; Lucie Storchová (ed.), Companion to Central and East European Humanism, II, Czech Lands (Part 1: A-L), Berlin 2020, pp. 298-316; for the critical edition of Collinus's Greek poems see Filippomaria PoNTANI - Stefan WeIse (eds.), The Hellenizing Muse - An Anthology of Poetry in Ancient Greek from the Renaissance to the

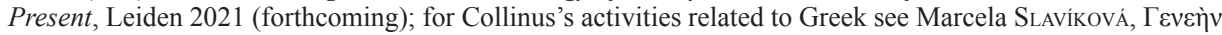
Boínuos: Humanist Greek Poetry in the Bohemian Lands, in: Commentationes Humanarum Litterarum 138, Helsinki 2020, pp. 247-267. 
Aeneid between 1541 and 1557, serves as an invaluable source of information about his Greek classes. However, while the volume itself is a rarity, the parallels to related contemporary texts are certainly worth examining. A useful comparison may be drawn with Commentarius explicationis primi libri Iliados (1538) by Joachim Camerarius, ${ }^{2}$ who, not unlike Collinus, was a former Wittenberg student and a professor of Greek at the universities in Tübingen and Leipzig. The main interest of the present paper is didactic: by comparing the texts by two professors of Greek who were contemporaries, I will draw conclusions as to the general tendencies that can be observed in lectures on Homer in the first half of the sixteenth century, while special focus will be placed on the structure, content, and objectives of the Greek lectures. As a secondary result, I will determine whether the two texts are directly related or, in other words, if the parallels between Camerarius's and Collinus's accounts mean that Collinus used the book by his former teacher ${ }^{3}$ as a source for his own lectures.

The volume titled Specimen studii ac laborum (1557) is a unique manuscript ${ }^{4}$ that Collinus had written in order to defend himself against accusations that he had been disseminating Lutheran ideas among students. Nevertheless, whatever the reason for the creation of the text, it was written by three of Collinus's students ${ }^{5}$ who had probably collected their notes from his lectures, which means that the volume can be considered authentic evidence of Collinus's teaching methods. The didactic part of the text begins ${ }^{6}$ with a three-page

2 Joachim Camerarius (1500-1574) learned Greek at the University of Leipzig, later he studied in Erfurt, and in 1521 he matriculated at Wittenberg, where he met Philipp Melanchthon, with whom he became the closest of friends. He taught Greek at Nuremberg gymnasium, at the University of Tübingen from 1535, and at Leipzig University from 1541 until his death. His many editions and translations include Sophocles, Herodotus, Aristotle, etc., and above all two volumes of Homer's Iliad. For detailed information on Camerarius see Joachim Hamm, Camerarius, Joachim d. Ä., in: Wilhelm Kühlmann et al. (eds.), Frühe Neuzeit in Deutschland 1520-1620. Literaturwissenschaftliches Verfasserlexikon (VL 16), Berlin - Boston 2011, pp. 425-438; Lothar Mund, Camerarius, Joachim, in: Wilhelm Kühlmann (ed.), Killy Literaturlexikon. Autoren und Werke des deutschsprachigen Kulturraums, II, Berlin - New York 2000, pp. 337-341; Rainer KössLING - Günther WARTENBERG (eds.), Joachim Camerarius, Tübingen 2003. See also John Edwin SANDYs, A History of Classical Scholarship: From the Revival of Learning to the End of the Eighteenth Century, Cambridge etc. 2010, pp. 266-267; Martin H. Jung, Philipp Melanchthon und seine Zeit, Göttingen 2010, pp. 71-72.

3 Collinus calls Camerarius his teacher in a letter dated 1554 (see Josef HeJnIC, Dva listy Matouše Collina z roku 1554 [Two Letters by Matthaeus Collinus from 1554], Zprávy Jednoty klasických filologů 15, 1973, pp. 44-62, esp. p. 49). It is apparent that Collinus and Camerarius maintained a correspondence, which might have even been regular, judging by the fact that Collinus mentions three of Camerarius's letters he had received. Unfortunately, it is not clear when exactly Collinus attended Camerarius's classes since their correspondence is yet to be fully collected and published. As far as is known, Collinus matriculated at Wittenberg in 1534, but he only received his master's degree in 1540, so it is imaginable that he might have visited Camerarius in the meantime, wherever he was teaching at the moment. The letter does not reveal what subjects Collinus studied under Camerarius.

4 The manuscript volume is located in the Österreichische Nationalbibliothek in Wien under inventory number Cod. 9910.

5 See Lucie StorchovÁ, Durchschnittliche Gelehrtenpraxis im Humanismus nördlich der Alpen? Der Umgang mit Homers und Vergils Epen in den Prager Universitätsvorlesungen des Matthaeus Collinus im Jahr 1557, Acta Musei Nationalis Pragae, Series C - Historia Litterarum 57/3, 2012, pp. 41-54, esp. p. 47. For the Specimen studii ac laborum see also A. Truhlář - K. Hrdina - J. HeJnIC - J. MartíneK, Rukovět' humanistického básnictví, pp. 429-430; see also Bohumil RyBA, Matouš Collinus a jeho vergiliovské universitni čteni [Matthaeus Collinus's University Lectures on Vergil], in: Otakar Jiráni - František Novotný - Bohumil Ryba (eds.), Pio vati. Sborník prací českých filologů k uctění dvoutisícího výročí narození Vergiliova, Praha 1930, pp. 95-111.

6 The volume opens with two dedications (see fols 1a-5b), both intended for Emperor Ferdinand I, before whom Collinus was supposed to defend his teaching methods. These dedications are excluded from the present research, since they contain little information relevant to this paper. 


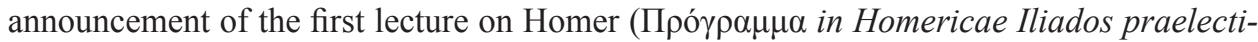
onem primam, anno 1541) composed in elegiac couplets, which, besides some personal information, ${ }^{7}$ includes reasons for reading and studying Homer. Collinus believes there is profound wisdom in Homer's books; ${ }^{8}$ nothing that happens in everyday life is omitte$\mathrm{d} ;{ }^{9}$ Homer explains things natural; and most importantly, he gives moral guidance ${ }^{10}$ by providing examples of virtue, bravery, and humanity. ${ }^{11}$ Moreover, the Greek language is beautiful. $^{12}$

The first lecture on Homer is different from the rest of the lectures in that it contains an

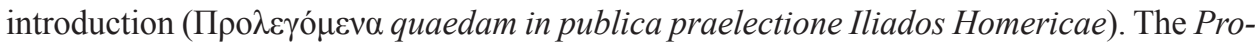
legomena, written in prose, begin on a moral note, with Collinus complaining about general laziness and barbaric contempt for the arts and humanities. ${ }^{13}$ However, the main body of his preface includes information about the author he is going to give lectures on (De autore) and about the book itself (De opere). The information about the author is divided into four parts, in which Collinus discusses 'Homer's name, his origin, his way of life, and when he lived' (De nomine, de patria, vitae genere et tempore, quo is vixerit).

Concerning the name, three etymologies are presented: either it means 'blind', as in

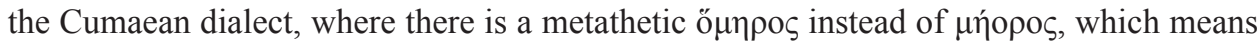
'not seeing'; or it is derived from the Greek word for hostage, i.e. ő $\mu \eta \rho \circ \varsigma$ again. Finally, he could have obtained the nickname because he had a hairy thigh since birth, hence the ó $\mu \eta \rho$ ó $\varsigma$, meaning the extremity or the leg. ${ }^{14} \mathrm{He}$ is called Melesigenes according to a certain river Meles and Maeonides because his father's name was Maeon. ${ }^{15}$ Homer's origin is very uncertain, as is attested by the famous verses supposedly preserved by Aulus Gellius in his Noctes Atticae 3.11:

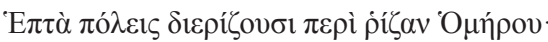

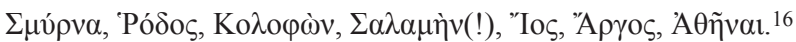

7 It appears that the lectures on Homer's Iliad that Collinus started giving in 1541 were his first public lectures ever, see fol. 6a: publica conscendi docturus pulpita nunquam. See ibid.: assuetus nec sum ferre docentis onus.

8 Fol. 6b: Illius in libris tanta est sapientia, quantam quantumvis summi non habuere oọoí.

9 Fol. 7a: Nilque fit in vita communi, cuius imago non aliqua in libris extet, Homere, tuis.

10 Ibid.: Tu regimen morum tradis, tu condita pandis naturae...

11 Ibid.: Ardua quam via sit virtutis monstrat Ulysses, fortis, in hoc pingis, quae sit imago viri.

12 Ibid.: Nam seu sermonem spectes, nil dulcius illo est...

13 Fol. 7b: Mihi maxime omnium placeret nunc instituere acerbam reprehensionem ignaviae et barbarici contemptus bonarum literarum, quem hactenus deprehendi in plurimis istorum, qui nihil nisi nomen, et vestitum fortassis, habent studiosorum hominum.

14 Fol. 8a: Alii dictum volunt Homerum lingua Cumana ab ipsa re seu effectu, quia scilicet caecus fuit. Cumani enim caecos homeros vocant; ö $\mu \eta \rho$ s ergo quasi $\mu$ jo os per metathesim literarum. Alii ab eventu hoc nominis

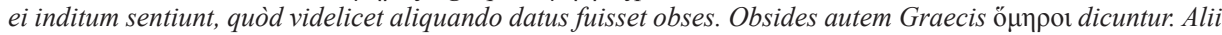
dictum volunt per admirationem, quasi ò $\mu \eta \rho$ ó, divisa voce, eo quòd alterum femur mox à nativitate hirsutum habuerit.

15 Ibid.: Antea Melisigenes (sic!) dictus fuisse perhibetur à fluvio quodam Melete, iuxta quem editus fertur à matre Critheide. Patrem eius aiunt vocatum Maeonem, à quo Maeonides interdum cognominatur.

16 [Seven cities fight over Homer's birth: Smyrna, Rhodes, Colophon, Salamis, Ios, Argos, and Athens.]; fol. 8b. Although the two lines and their variants are certainly very famous and still belong to the basic knowledge of any student of ancient Greek, no such verses can be found in the modern editions of Gellius's Noctes Atticae; see John C. Rolfe (ed. et trans.), The Attic Nights of Aulus Gellius, with an English Translation, Cambridge Massachusetts - London 1927, p. 276. However, early modern printed editions did contain the verses as quoted by Collinus, see e. g. Auli Gellii luculentissimi scriptoris Noctes Atticae...Petri Mosellani...annotationes, 
Homer's life was similar to that of a beggar's. ${ }^{17}$ Finally, he lived immediately after the Trojan War and 160 years before Rome was founded, which was in the time of King Jehoshaphat. 18

This is followed by information about the book itself, which, once again, is divided into four parts. Firstly, the content of the book (res, quae hic tractantur) is discussed. Homer is the source of all philosophy; there is nothing in this world whose example cannot be found in Homer. He is a mirror of all civic actions and heroic virtues and teaches us about making judgements and about wisdom. ${ }^{19}$ Next, the type of discourse (genus orationis) is described, which excels both in poetic expression and rhetoric devices. And there are many Greek words in Latin, so whoever learns Greek is also able to improve their Latin. ${ }^{20}$ Then the title of the book (titulus operis) is explained, ${ }^{21}$ and, finally, the poet's reasons (consilium poetae) for composing the book are stated: he wanted to bring fame to his nation, disgrace barbarians, and give examples of virtues. ${ }^{22}$ This is the last point of Collinus's Prolegomena, which must have actually been read in his first lecture on Homer. The short summary of the entire Iliad (De oeconomia totius huius operis) that follows must have been part of the second lecture.

Aside from the Prolegomena, there are twenty-four lectures on each book of Iliad in the Specimen studii ac laborum, all exhibiting the same pattern. Each lecture was divided into five parts. First of all, Collinus presented a short Latin summary of the book written in prose (Summa libri). Next, he discussed the plot in detail, once again in prose (Capita libri), which he retold in Latin hexameters (Idem argumentum heroicis versibus comprehensum). Then he enumerated moments and events in the book that are worth remembering (Loci memorabiles) because they contain a moral or a lesson to be learned. These already comprised Greek quotations from the book that were always provided with a literal Latin

Coloniae 1537, apud Ioannem Gymnicum, p. 144. Today the variants of the verses can be found in the Greek Anthology, see Anthologia Graeca 16.297.1 and 16.298.1.

17 Fol. 8b: Vitae genus ipsius fuit per omnia conveniens fortunae poeticae, quae non multum discrepat à sorte mendicorum. Cursitabat enim hinc inde per Graeciam, quaeritans sibi victum sua poetica arte suisque carminibus, sed parum obtinebat...

18 Fol. 9a: Vixisse dicitur Homerus anno post Troianum bellum et ante Romam conditam 160, temporibus Iosaphat regis Iudae, qui quintus fuit à Davide, circa cuius tempora bellum Troianum gestum esse dicitur.

19 Fols. 9a-9b: Quod ad res attinet, dubium non est in hoc poemate gravissimam contineri doctrinam, quae ad omnes philosophiae partes referri potest et solet. Ideoque sapientissimi homines Homerum vocant fontem totius philosophiae....nihil posse in vita cogitari, cuius non aliquod simulachrum extet in Homero. Item hunc autorem esse speculum quoddam omnium negociorum civilium et heroicarum virtutum.... discemus hinc multa ex omnibus philosophiae partibus, quae conducunt ad formandum iudicium de rebus variis et ad alendam in nobis prudentiam.

20 Fols 10a-10b: ...nec poetica modò, sed oratoria virtute eminentissimus (see Quintillianus, Institutio Oratoria 10.1.47.1). Hic ergo alter petetur ex hac lectione fructus, videlicet facultas seu occasio excolendae et locupletandae linguae...neminem unquam plenè addiscere posse Latinam linguam, qui Graecam non calluerit...

21 Fol 11a: Inscribitur autem opus hoc Ilias, quae vox terminatione quidem est patronymica in genere foeminino. Caeterum significationem habet possessivi iuxta dialectum Aeolicam. Aeoles enim patronymica pro possessivis usurpant. Ilias ergo deducitur à nomine Ilios, quod urbis fuit nomen in Asia minore, sic dictae ab Ilo Trois regis filio, patre Laomendontis.

22 Fol. 12a: Quartò, consilium texendae huius historiae hoc haud dubiè habuit poeta, quòd non solum voluit celebrare suam gentem ac simul insectari barbaros, sed etiam proponere singulare exemplum parum virtutum, quibus praestans bellator in armis tempore belli praeditus esse debeat. 
translation. ${ }^{23}$ The same can be said about the concluding part of Collinus's lessons, where he examined the Loci communes, i.e. the universal truths. ${ }^{24}$

There is not much Greek in Collinus's lectures, each containing four or five Greek quotations on average, which clearly shows that the primary purpose of his lectures on Homer was not language instruction but rather the use of the text to expound on common truths and moral values. Such an approach was typical for Philipp Melanchthon's lessons, whose methods Collinus had apparently adopted ${ }^{25}$ during his studies at Wittenberg University. However, it must also be taken into account that when Collinus started giving lectures on Homer's Iliad in 1541, only a select few of his learned contemporaries knew Greek, as a result of having studied in Wittenberg or Leipzig. But those would hardly have been his students. Neither is it very probable that his learners would have already known at least the basics of Greek, since the time when Greek was taught at Bohemian Latin schools was yet to come. ${ }^{26}$ So, it is only natural that he had to explain as much as possible in Latin. If the most recent lectures contain some longer quotations from Homer, it must be due to the grammar lessons he gave.

There are also announcements of his lectures and lessons in the Specimen studii ac laborum, some of which are rather informative. We learn that he taught Greek grammar using the Institutiones Graecae Grammaticae by brother Urbanus that was first published in 1497, and it also appears that the students were supposed to have Greek texts at the lectures, ${ }^{27}$ although it might have seemed otherwise from what was said above. It is further evident from an announcement dated 21 October 1545 that Collinus had difficulties with poor attendance in his classes and that he genuinely struggled to motivate students for the subject. ${ }^{28}$

The comparison with Commentarius explicationis primi libri Iliados by Joachim Camerarius $^{29}$ may not seem entirely relevant, seeing as Camerarius's book is a full and detailed commentary on Homer's text, while Collinus's Specimen studii ac laborum is but an authentic sketch of his lectures. However, upon closer examination of Camerarius's Commentarius, some striking similarities emerge. The author also states that after he had devoted considerable effort to explaining Homer to students in Tübingen, he decided to

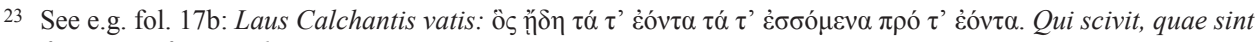
fuerintque futura vel essent.

24 See e.g. fol. $19 \mathrm{~b}$ about obeying the rulers since they were appointed by God (Praeceptum Nestoris de obedientia praestanda superioribus magistratibus, quòd hi imperium à Deo habeant).

25 See L. StorchovÁ, Durchschnittliche Gelehrtenpraxis, pp. 41-54.

26 Actually, there is not much direct evidence that Greek was taught at Latin schools at all, and what information does exist is of a much later date. See Zikmund WiNTER, Život a učení na partikulárních školách v Čechách $v$ XV. a XVI. stoleti [The Life and Learning at Particular Schools in Bohemia in the 15th and 16th Centuries], Praha 1901, pp. 547-553.

27 Fol. 227b: Interea parent sibi adolescentes exemplaria Homericae Iliados, Grammatices Urbani et tabularum Ioannis Murmellii De versibus faciendis... Itaque qui non habent excusos codices, describant sibi textum Graecum aliunde...

28 See fol. 229b: Clamamus saepius in hoc loco, lector, clamamus, sed non exaudimur; invitamus, sed contemnimur; docemus, sed paucissimi doctrinam nostram accipere volunt, si tamen volunt accipere, ac non potius legum et magistratus auctoritate compulsi, tamen nobis docentibus assidere solent instar statuarum omni animorum concepto carentium; usque adeo nunc effrenis ac literarum bonarum contemptrix iuventus nostra degeneravit à moribus veterum studiosorum Boiemici nominis...

29 Commentarius explicationis primi libri Iliados Homeri, Ioachimi Camerarii Pabergensis, s. 1. 1538, cum gratia et privilegio imperiali. 
meet his friends' wishes and publish his 'dictata', i.e. his lectures. ${ }^{30}$ That he did not intend Commentarius to be his individual work but wanted it rather to be counted among the school's achievements is apparent from another remark of his by which he expresses the hope that the book will bring honour to the Tübingen school once everybody knows that Homer is valued and practised there. ${ }^{31}$ Thus, the purpose of the two books may not have been as different as it might at first seem.

The preface to the first book (In primum librum Iliados Homeri praefatio) includes much information, but the important notion is that it contains all the main points we observed in Collinus's Prolegomena. Not only is there the complaint about the general contempt for the arts and letters, ${ }^{32}$ but the reasons for studying Homer's texts are identical to those presented by Collinus, namely the universal knowledge ${ }^{33}$ that Homer's texts contain, his depiction of nature, virtues, and morals, ${ }^{34}$ the rhetorical aspect ${ }^{35}$ of the text, and also its beauty. ${ }^{36}$

This is followed by information about the author (De autore) and the work (De opere), which in general is very similar to Collinus's account, both in content and division, ${ }^{37}$ although the corresponding sections are presented in a different order. Obvious similarities can be observed in the section on Homer's name, where the authors even use the same vocabulary. ${ }^{38}$ Nevertheless, some important details do not concur, e.g. Camerarius does not mention Homer's father, Maeon, as Collinus does, but he does elaborate on his death and the question of the so called Homeridai, which Collinus omits. Considerable differences can be observed in their respective accounts on the period Homer was supposed to live in and also in the section they titled De genere orationis or scripti, ${ }^{39}$ while the parts about the title and poet's intentions are similar once again. Camerarius, however, proceeds much further in his Commentarius when he adds a list of ancient editors of Homer's books and

30 Fol. A2b: Ego hoc tempore opera, ut confido, non prorsus contemnenda, in Homero explicando discipulis nostris impensa cum hortantibus amicis ad dictatorum aeditionem morem gerere statuissem...

31 Fol. A4a: Decrevimus primum librum Iliados Homericae feriarum diebus publice amatoribus optimarum disciplinarum et humanitatis interpretari et hanc etiam laudem conciliare huic scolae, ut in ea monumenta celebrari dicantur eius autoris, qui omnium consensu princeps ingenii, doctrinae, sapientiae habetur.

32 This complaint can actually be found in the dedication letter (Epistola nuncupatoria, Bolgango Augusto Severo) that precedes the preface to the first book, see fol. A3a: Requiritur autem profecto magna quaedam vis defensionis ... artium atque studiorum humanitatis. ... Ipsorum vero nuditas atque exilitas et despectui et direptioni audacioribus esse solet.

33 Fol. A4a: (monumenta eius) ut virtutem...ita ipsam eruditionem universam comprehendunt atque includunt; fol. B3a: ...Sed Homerus omnium saeculorum atque gentium consensu vel unus propriam vel praecipuam hanc famam meritus consecutusque est, cuius quidem versibus nemo inter doctos reperitur, qui dubitet, quin omnia ea, de quibus praecepta artium tradi possint, vel designata vel expressa sint.

34 Fol. B1a: ...studia, quae doctrinam virtutis complectuntur; fol. B4a: Reliqua sunt doctrinae genera duo, de natura et moribus.

35 Fol. B3b: ... manifestum est, cum nulla orationis figura...cuius in isto exemplum non sit...Idem statuendum de toto artificio dicendi, quid est et in certitudine et in facundia, illo magistro cognitum et usurpatum.

36 Fol. C4b: At poetae et deligere praecipua et ea sic proponere, ut quasi redimita ornatu verborum et compositionis gratissima et amabilissima redderent. Quorum principem Homerum et praestantem in utroque esse scirent.

37 For easier comparison of the data, I include two tables in which the main points of Collinus's and Camerarius's accounts are summarized, see the appendix to the present paper, pp. 215-216.

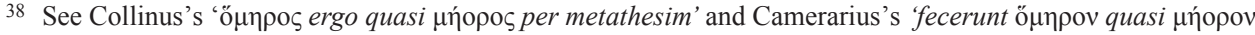
per metathesin' in the sections on Homer's name (De nomine and Origo et nomen, p. 215); see also ibid. Collinus's 'Per admirationem...femur...hirsutum' as opposed to Camerarius's 'Hirsutum femur...propter admirationem...' and Collinus's 'à fluvio quodam Melete' and Camerarius's 'à fluvio Melete'.

39 Collinus expounds on the artistic qualities of Homer's language and discusses the practical purpose of Greek studies, whereas Camerarius explains the difference between poetry and prose. 
a very detailed interpretation of the text, explaining almost each word and sometimes its grammatical or metrical peculiarities. There are numerous examples from ancient authors, such as Euripides, Vergil, Horace, and many others. There are also family trees of heroes and gods, so basically any relevant information that might cross the reader's mind. Next comes a Greek summary of the first book, Homer's Greek text, and a non-literal Latin translation in hexameters, which was clearly inspired by Vergil's Aeneid. ${ }^{40}$

The detail Camerarius provides in his Commentarius may seem to suggest that his lectures were entirely different from those of Collinus, who clearly read all twenty-four books of Homer's Iliad, probably even in only twenty-five lessons. Yet it is highly improbable that Camerarius would have had enough time to proceed in such detail in his lessons, and neither does it appear likely that he would have simply skipped most of Homer's Iliad to allow for such a thorough approach in the first two books. ${ }^{41}$ By doing so, he would have missed important moral values that Homer's text only provides if read in its entirety. ${ }^{42}$ It must, therefore, be concluded that whatever he says about 'publishing his lectures' 43 should be regarded with caution, as he could have clearly included only some information provided by his Commentarius. This does not, however, entail that Commentarius was not meant for school purposes. There are quotations from Greek authors presented in a Latin translation because they could have proved difficult for the students, ${ }^{44}$ and there is also the parallel Latin translation, which includes sentences and words that every student knew by heart. ${ }^{45}$ This suggests that Commentarius was intended for further individual reading. Thus, only little can be deduced about Camerarius's lectures from his Commentarius. Nevertheless, it is debatable whether they would have been very different from those of his contemporaries such as Philipp Melanchthon and Veit Winsheim, from whom Collinus learned. Considering the fact that Camerarius and Melanchthon were colleagues and the closest of friends, it is likely they would have discussed their views on what shape the lectures on Homer should take. Melanchthon's Praefatio in Homerum Viti Winsemii ${ }^{46}$ proves that they indeed had some ideas in common. Not unlike Camerarius and Collinus, Melanchthon appreciates the profound wisdom and moral values that Homer's text contains as well as its beauty. ${ }^{47}$ While

40 See fol. R4a, v. 7: Musa, mihi caussas memora quo nomine primum quove deo ductor Graecorum, which is an obvious paraphrase of Vergil's Aeneid 1.8. although other major Roman poets who were an integral part of the school curriculum are also strongly represented in Camerarius's translation; for an allusion to Ovid's Metamorphoses 3.504 see fol. R4a, v. 3: inferna sede receptis; for Lucretius, De rerum natura 5.801 and 5.1078 see ibid., v. 4: variaeque volucres; et al. See also Asaph Ben-Tov, Lutheran Humanists and Greek Antiquity, Melanchthonian Scholarship between Universal History and Pedagogy, Leiden - Boston 2009, p. 171.

41 Camerarius also commented on the second book of Homer's Iliad, see Commentarii explicationum secundi libri Homericae Iliados...autore Ioachimo Camerario Pabergensi, s. 1. 1540, cum gratia et privilegio imperiali.

42 For moral guidance as one of the reasons for studying Homer see above, p. 212, note no. 34. Pontani even believes that it was the ethical aspect of Homer's text that Camerarius valued most, which would mean that his main goal would not have been different at all from that of Collinus. See Filippomaria Pontani, From Budé to Zenodotus: Homeric Reading in the European Renaissance, International Journal of the Classical Traditions, 14, 3/4, 2007, p. 385.

43 See above, p. 212 and note no. 30.

44 See fols C3a-b where quotations from Sophocles, Euripides, Theognis, and Homer are presented in Latin, probably for easier comprehension.

45 See above, note no. 40 .

46 See Praefatio in Homerum Viti Winsemii (1538), in: Philippi Melanchthonis cum praefationum in quosdam illustres autores, tum orationum de clarissimorum virorum vitis. Tomus secundus, Argentorati 1569, pp. 31-59.

47 See Praefatio in Homerum, p. 38: Ac primum quidem sic statuo nullum unquam scriptum, inde usque à primum condito orbe, ulla in lingua aut natione ab ullo humano ingenio aeditum esse, sacra ubique excipio, in quo vel 
it is undoubtable that Collinus's views and, consequently, his lectures must have been strongly influenced by Melanchthon, whose diligent student he used to be in Wittenberg, ${ }^{48}$ it is not entirely certain that Camerarius ever attended Melanchthon's classes. ${ }^{49}$ When he came to Wittenberg in 1521, he had already learned Greek from Richard Croke and Petrus Mosellanus in Leipzig. ${ }^{50}$ It is, therefore, possible that the notions they have in common might have been discussed prior to either Camerarius or Melanchthon. However, it is equally likely that as colleagues and close friends who maintained contact from early adulthood, they could have influenced each other's ideas. ${ }^{51}$ But Melanchthon's Praefatio in Homerum is not a detailed commentary on Homer's text, neither is it an authentic sketch of lectures on Homer's Iliad, which means that it lacks most of the information found in Collinus's and Camerarius's volumes. They must have drawn upon other sources too. Camerarius had the D-scholia at hand, which he also used for commented editions of Iliad and Odyssey, published in 1541 and 1551, respectively. ${ }^{52}$

Regarding the parallels between Collinus's and Camerarius's volumes, they do not necessarily prove that Collinus used Camerarius's Commentarius as a source for his own lectures, even though it is easily imaginable that as a former student who was in contact with his teacher he might have had the book at his disposal. Nevertheless, despite some marked similarities and many of the same quotations, there is information in Collinus's Specimen that cannot be found in Camerarius's Commentarius. Therefore, he must have used another source for his lectures. The most obvious solution is that he turned to his former Wittenberg teacher Veit Winsheim, who as an expert on Homeric epic was perfectly capable of working with scholia and producing an interpretation that was similar but not identical to Camerarius's. ${ }^{53}$

doctrinae tantum sit, vel elegantiae et suavitatis. See ibid. pp. 38-39: Quod enim dabitis mihi praeceptum ad mores, ad vitam bene ac foeliciter instituendam, unquam à viris sapientibus proditum, cuius non sit in Homero aliquod speciosum et illustre exemplum. Quod in vita officium, aut quod omnino negocium, cuius non in eodem expressa sit imago?

48 As far as is known, Collinus studied Greek under Veit Winsheim, but attended other classes given by Melanchthon.

49 Camerarius is sometimes referred to as Melanchthon's student, see Risto SAARINEN, Weakness of Will Renaissance and Reformation Thought, New York 2011, p. 142. However, disregarding the fact that Camerarius was only three years younger than Melanchthon, it is unlikely that he would have not mentioned his studies under Melanchthon in the preface to his Vita Philippi Melanchthonis (Hagae-Comitum 1655, Ex typographia Adriani Vlacq), where he is rather specific about how they met and about their relationship. See fol. 1a: Multa autem mihi nota esse (sc. de Philippo Melanchthone) arbitrabantur, quem et celeriter in ejus familiaritem pervenisse, cum ille primùm sese in has regiones contulisset, et conjunctissimè cum ipso vixisse scirent... vera amicitia usus...Saepe literas mihi ab eo non aliter quam fratris nomine inscriptas legerant. Saepe viderant, quam amanter ipse me coram complecteretur et de me absente sermones honorificae inprimis mentionis audiverant.

50 See pp. Peter G. Bietenholz - Thomas B. Deutscher (eds.), Contemporaries of Erasmus, A Biographical Register of the Renaissance and Reformation, 1, Toronto - Buffalo - London 1995, pp. 247-248.

51 For Melanchthon's and Camerarius's correspondence see H. ScheIBLE (ed.), Melanchthon's Briefwechsel, Kritische und kommentierte Gesamtausgabe, Regesten, 12 Bde., Stuttgart 1977-2005.

52 See F. Pontani, From Budé to Zenodotus, p. 384. For the editions see Opus utrumque Homeri Iliados et Odysseae, diligenti opera Iacobi Micylli et Ioachimi Camerarii recognitum, Basileae 1551, per Ioan. Hervagium.

53 No Winsheim's commentary on Homer survives; there is only Philipp Melanchthon's Praefatio in Homerum Viti Winsemii, which probably served both as an invitation to his lecture and as an introduction to Winsheim's commentary. 


\section{Annexe}

Collinus, Specimen ( $8 \mathrm{~b}-9 \mathrm{~b})$

\section{DE AUTORE}

De nomine

Cumani enim caecos homeros vocant;

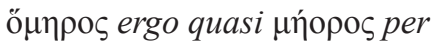

metathesim literarum.

Obsides autem Graecis ö $\mu \eta \rho о$ dicuntur.

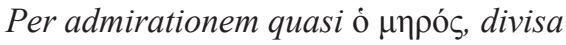
voce, eo quòd alterum femur mox à nativitate hirsutum habuerit.

....Melisigenes (!) dictus fuisse... à fluvio quodam Melete.

Maeonides (patrem eius aiunt vocatum Maeonem).

\section{De patria}

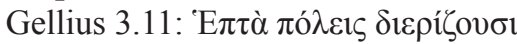

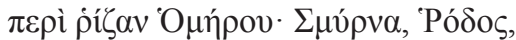

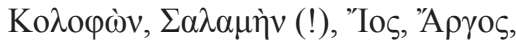
A $\theta \tilde{n} v \alpha$.

\section{De vitae genere}

Non multum discrepat à sorte mendicorum.

\section{De tempore, quo is vixerit} Anno post Troianum bellum et ante Romam conditam 160, temporibus Iosaphat regis Iudae.
Camerarius, Commentarius (D1b-D3a)

DE AUTORE

Patria et civitas

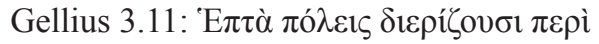

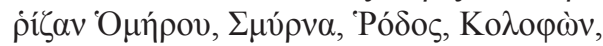

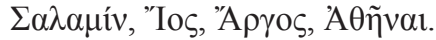

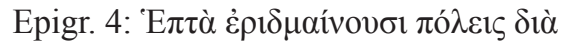

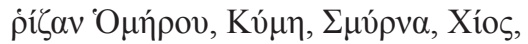

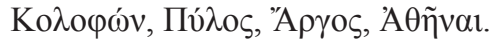

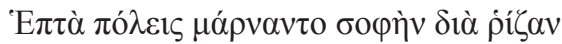
Ouńpov,

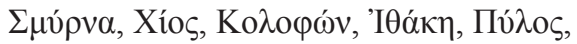

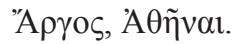

\section{Vita et fortunae}

...tota ubique Graecia vagantem prope mendicasse victum.

\section{Tempus, quo vixerit}

Tanta est in temporibus notatis diversitas et incertitudo.

\section{Origo et nomen}

...à fluvio Melete Melesigenem...

...Homerum, quo lingua Cumaea caecus significetur... fecerunt ö $\mu \eta$ opov per metathesin.

...obsides autem Graece ö $\mu \eta p o r$ sunt. Hirsutum femur habuisse... propter admirationem ó $\mu \eta \rho o ́ s$, id est femur, appellaretur.

\section{Mortis genus}

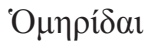




\section{DE OPERE}

\section{Res, quae hic tractantur}

Homerum vocant fontem totius

philosophiae; nihil posse in vita cogitari, cuius non aliquod simulachrum extet in Homero; hunc autorem esse speculum quoddam omnium negociorum civilium et heroicarum virtutum.

\section{Genus orationis}

Nec poetica modò, sed oratoria virtute eminentissimus; neminem unquam plenè addiscere posse Latinam linguam, qui Graecam non calluerit.

\section{Titulus operis}

Vox terminatione quidem est patronymica in genere foeminino; significationem habet possessivi... deducitur à nomine Ilios, quod urbis fuit nomen...sic dictae ab Ilo Trois regis filio, patre Laomedontis.

\section{Consilium poetae}

Celebrare suam gentem ac simul insectari barbaros; proponere singulare exemplum parum virtutum, quibus praestans bellator in armis tempore belli praeditus esse debeat.

\section{De genere scripti}

Eorum, quae oratione exponi solent, una est divisio compositionis. Nam

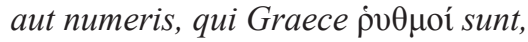
concinnata illa ita est, ut $\mu \varepsilon \dot{\tau} \rho \alpha$ sint, qui versus dicuntur, aut soluta hac lege fertur libera, quae dicitur prosa oratio...

\section{De titulo operis}

...patronymica forma...ab Ilio, quae appellatio urbis esset Troianae, ab Illo patre Laomedontis, cuius est nomen apud Homerum foemininum.

\section{De consilio autoris}

Consilium autoris atque voluntas fuit exemplum quoddam singulare fortitudinis hoc opere suo proponere et Graecos ornare atque insectari planeque infamare barbaros. Denique celebrare praedicatione sua res Graeciae.

\section{Operis distinctio}

Argumenta autem, hoc est summae librorum et ut Graeci vocant $\pi \varepsilon \rho 10 \chi \alpha i$, ante explanationem singulorum rectissime exponentur...Et nos de Iliade versus Graecos, argumenti loco propositos, singulis libris singulos Latine factos subiecimus.

\section{De interpretibus Homericis}

Zenodotum igitur primum tradunt, potiente rerum in Aegypto Ptolemaeo Philadelpho, Homericos libros collegisse et correxisse. Qui et autor fuerit.. 


\section{PŘEDNÁŠKY O HOMÉROVI NA NEKATOLICKÝCH UNIVERZITÁCH STŘEDNÍ EVROPY NA ZÁKLADĚ DĚL SPECIMEN STUDII AC LABORUM (1557) MATOUŠE COLLINA A COMMENTARIUS EXPLICATIONIS PRIMI LIBRI ILIADOS (1538) JOACHIMA CAMERARIA}

\section{Grant support:}

This study is a result of the research funded by the Czech Science Foundation as Project GA19-04340S 'Europa humanistica II. Editing and Translating Ancient Classics in the Czech Lands at the Turn of the 16th Century' and based at the Institute of Philosophy.

\section{RESUMÉ}

Studie podrobně analyzuje Specimen studii ac laborum (1557) Matouše Collina (1516-1566) a rozebírá strukturu, obsah a cíle přednášek o Homérovi, které měl Collinus na pražské univerzitě mezi lety 1541 a 1557 . Srovnání se spisem Commentarius explicationis primi libri Iliados (1538) Joachima Cameraria umožňuje vyvodit závěry nejen ohledně obecných tendencí ve výuce řečtiny na středoevropských nekatolických univerzitách v první polovině šestnáctého století, ale především o tom, zda je mezi oběma studovanými texty př́má souvislost, tj. zda Collinus použil Camerariův Commentarius jako zdroj pro své vlastní výklady.

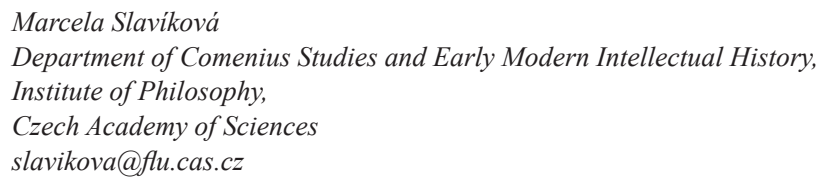

